KINETIK, Vol.1, No.2, Agustus 2016, Hal. 47-54

ISSN : 2503-2259,

E-ISSN : 2503-2267

\title{
Rancang Bangun Sistem Monitoring Listrik Prabayar dengan Menggunakan Arduino Uno
}

\author{
Diah Risqiwati ${ }^{*}$, Ahmad Ghozali Rizal ${ }^{2}$, Zamah Sari ${ }^{3}$ \\ $1,2,3$ Universitas Muhammadiyah Malang \\ risqiwati@umm.ac.id ${ }^{* 1}$, aries_echa1@yahoo.co.id², abdzamahsari@gmail.com³
}

\begin{abstract}
Abstrak
Kebutuhan akan listrik akan terus meningkat dari tahun ke tahun, hal ini dikarenakan pembuatan produk yang menggunakan listrik sebagai energinya juga gencar dikeluarkan oleh produsen sehingga kebutuhan akan listrik sudah menjadi kebutuhan yang sangat vital untuk masing-masing individu. Dikarenakan pelanggan tidak mengetahui beban dari alat listrik yang digunakan sehingga tidak dapat melakukan kontrol dari pulsa listrik yang dibeli. Dari permasalahan itu, peneliti mengusulkan untuk membuat suatu alat kontrol dengan menggunakan Arduino Uno, sehingga pemilik dapat mengontrol penggunaan listriknya secara real time. Board Arduino berfungsi sebagai sistem kontrol pengambilan data, sebelum data tersebut diolah pada server. Terdapat sistem sensor berfungsi untuk pengambilan data Ampere, yaitu sensor AC712-20A dan modul relay sebagai sakelar elektrik berfungsi untuk memutus daya listrik ketika pulsa tidak mencukupi. Dari hasil pengujian yang telah dilakukan, terdapat kesalahan pengukuran rata-rata sensor ACS712-20A dengan multitester sebesar 26\%, sedangkan untuk pengukuran billing listrik prabayar terdapat kesalahan sebesar $6 \%$.
\end{abstract}

Kata kunci: Listrik prabayar, Arduino Uno, Sensor ACS712-20A, Relay

Abstract
The demand of electricity is increasing as the consequences of numerous electronics produced and making it as the basic need for everyone nowadays. However, many electricity customers do not know precisely the power bandwidth for each electronic product they used and find difficulties to control their credit for electricity supply. Therefore, the researcher aims to develop a control aid using Arduino Uno to help them check their real-time electricity consumption. Board Arduino is functioned as the data-taking control system before the data sent to the server. AC712-20A sensor is employed to count the Ampere data and Relay Module is to switch off the electricity when the credits are no longer sufficient to cover the needs. Based on the research conducted, AC712-20A sensor shows 26\% measurement error in average and 6\% measurement error in pre-purchased electricity billing.

Keywords: Prepaid Electricity, Arduino Uno, Sensor ACS712-20A, Relay

\section{Pendahuluan}

Listrik merupakan kebutuhan wajib bagi manusia saat ini. Semua peralatan sebagian besar memakai listrik sebagai energinya. Kebutuhan akan listrik dari tahun ke tahun semakin besar, hal ini dikarenakan produsen juga semakin gencar memproduksi berbagai macam peralatan yang fungsinya beragam untuk membantu dan memenuhi kebutuhan manusia, mulai alat-alat elektronik rumah tangga, alat-alat kantor, industri, peralatan olah raga, serta peralatan yang lebih privasi lagi seperti smartphone dan lain sebagainya.

Saat ini di Indonesia tengah diimplementasikan listrik prabayar selain listrik pasca bayar yang sudah ada sebelumnya. Layanan ini mempunyai keunggulan dibanding teknologi terdahulu, karena pelanggan dapat mengontrol biaya pengeluaran dari kebutuhan listrik, seperti mengisi pulsa melalui ponselnya. KWh listrik juga dapat dipantau, sehingga kebutuhan listrik dapat dirancang sesuai anggaran. Pencatatan kWh membuat listrik prabayar menjadi semakin diminati karena pencatatannya dianggap lebih akurat daripada listrik pasca bayar. Pembelian pulsa kWh juga dapat dibeli di mana saja, sehingga sistem ini juga dinilai lebih praktis dan memudahkan pengguna. Namun, kenyataannya pencatatan $\mathrm{kWh}$ listrik tidak dapat dikontrol secara real-time, sering kali terjadi pemakaian yang over budget. Sehingga pelanggan harus 
membeli pulsa kWh lagi dikarenakan listrik adalah kebutuhan yang sangat penting sekali untuk mendukung segala kegiatan. Dengan demikian, penulis mengusulkan penelitian tentang implementasi Arduino Uno untuk pengukuran listrik prabayar, agar listrik dapat dikontrol secara real-time disesuaikan dengan penggunaan perangkat yang sedang on. Sistem yang akan dibuat penulis ini dapat pula dikembangkan untuk smart home energy management [1].

Wattmeter digital merupakan alat ukur yang sudah banyak dibuat atau diteliti oleh banyak orang. Salah satunya Ageng Pidaksa (2011) dalam penelitian wattmeter digital. Wattmeter yang diteliti menggunakan sensor yang sama, yaitu ACS 712 [2]. Sistem kontrol menggunakan perangkat keras ATMega 8. Daya yang dibaca hanya satu sumber, serta sistem yang dibuat, tidak dilengkapi dengan menu pengaturan dan tidak adanya interaksi monitoring antara perangkat pengukur dengan PC.

Dalam penelitian ini, Arduino memiliki banyak modul pendukung (shield, sensor, tampilan, penggerak dan sebagainya) dan mampu diintegrasikan dengan jaringan lokal maupun internet sehingga data dapat dikelola oleh web service. Web service merupakan suatu sistem yang dirancang untuk mendukung interoperabilitas dan interaksi komunikasi antar sistem (aplikasi) dalam suatu jaringan [3]. Penggunaan web service banyak digunakan untuk penyediaan data ke public. Board Arduino berfungsi sebagai sistem kontrol pengambilan data, sebelum data tersebut diolah server. Terdapat sistem sensor berfungsi untuk pengambilan data Ampere, yaitu sensor AC712-20A dan modul relay sebagai sakelar elektrik berfungsi untuk memutus daya listrik ketika pulsa tidak mencukupi. Masing-masing sensor akan terhubung langsung dengan peralatan listrik yang sedang on, beban listrik akan dihitung oleh sensor dan akan diolah oleh Mikrokontroller Arduino Uno untuk selanjutnya diolah pada server sehingga kebutuhan listrik secara real-time dapat dihitung. Untuk membandingkan keakurasian dari sensor, tiap-tiap perangkat akan diukur bebannya dengan Multimeter secara langsung dan hasil keduanya akan dibandingkan.

\section{Metode Penelitian}

\section{A. Topologi Jaringan Listrik Prabayar}

Secara garis besar dalam perancangan arsitektur sistem ini, sebelum listrik PLN masuk ke jaringan instalasi listrik masing-masing kamar terdapat relay yang berfungsi sebagai sakelar on/off, sakelar ini dipengaruhi oleh kondisi pulsa listrik saat pulsa mencukupi, untuk selanjutnya sensor ACS712-20A meng-capture beban Ampere pada masing-masing kamar, karena data masih berupa data Analog, sehingga butuh diproses menjadi data digital dan dikirimkan ke web service yang melewati koneksi jaringan TCP/IP. Sistem akan melakukan polling setiap interval 3 menit dan melakukan pengecekan kondisi keadaan pulsa pada channel tertentu. Jika pulsa mencukupi maka server prabayar akan mengirimkan perintah untuk mengaktifkan mekanik relay. Gambar 1 menunjukkan arsitektur secara global sistem jika diimplementasikan. Gambar 2 merupakan detail dari sistem listrik prabayar.

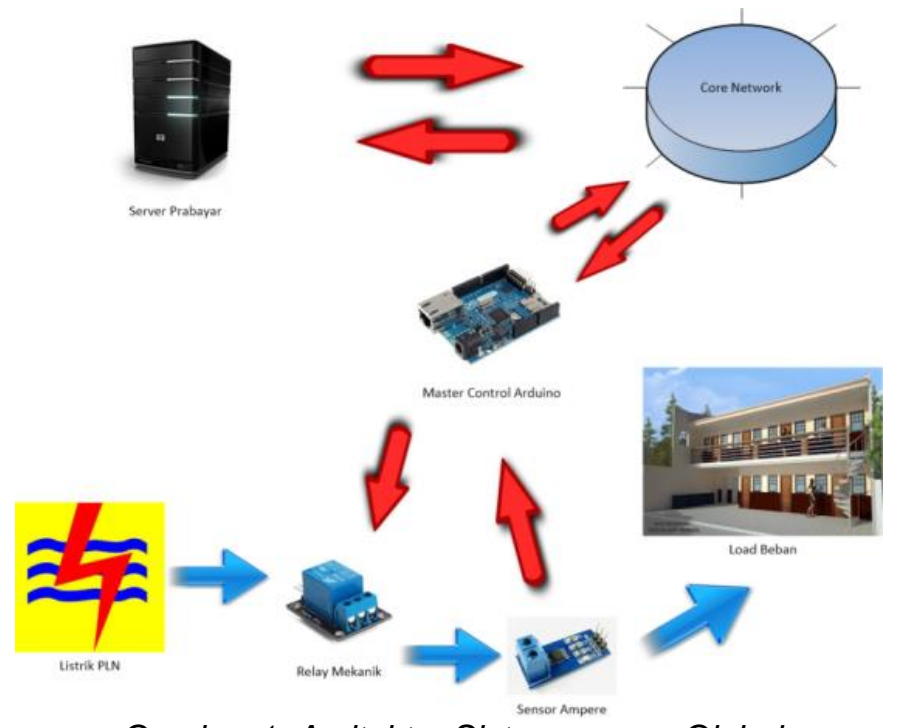

Gambar 1. Arsitektur Sistem secara Global 


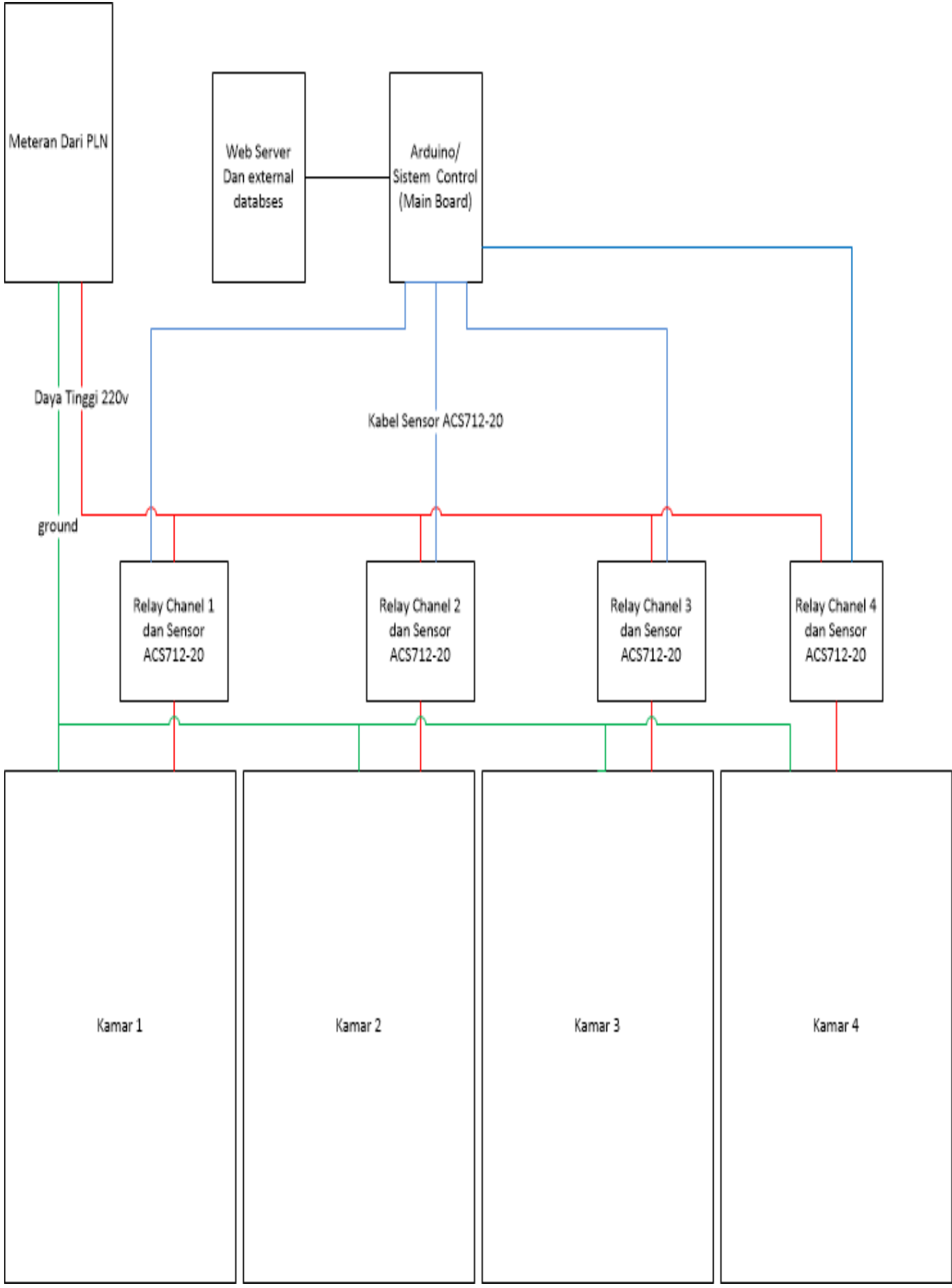

Gambar 2. Arsitektur Sistem secara Detail

\section{B. Diagram Alur}

Gambar 3 merupakan diagram alur program listrik prabayar pada kost mahasiswa menggunakan Arduino Uno yang berada pada server side. Pertama, server harus mengetahui arus masing-masing channel dan status pulsa. Jika pulsa masih mencukupi, sistem akan melakukan pengurangan pulsa secara otomatis dengan acuan terdapat peningkatan Ampere pada channel, setiap interval 3 menit maka data di dalam database akan di update. Data tersebut digunakan untuk membuat sistem informasi penggunaan daya listrik yang akan di update setiap 
interval 60 menit, sehingga didapat data kWh. Data tersebut akan ditampilkan dalam bentuk grafik.

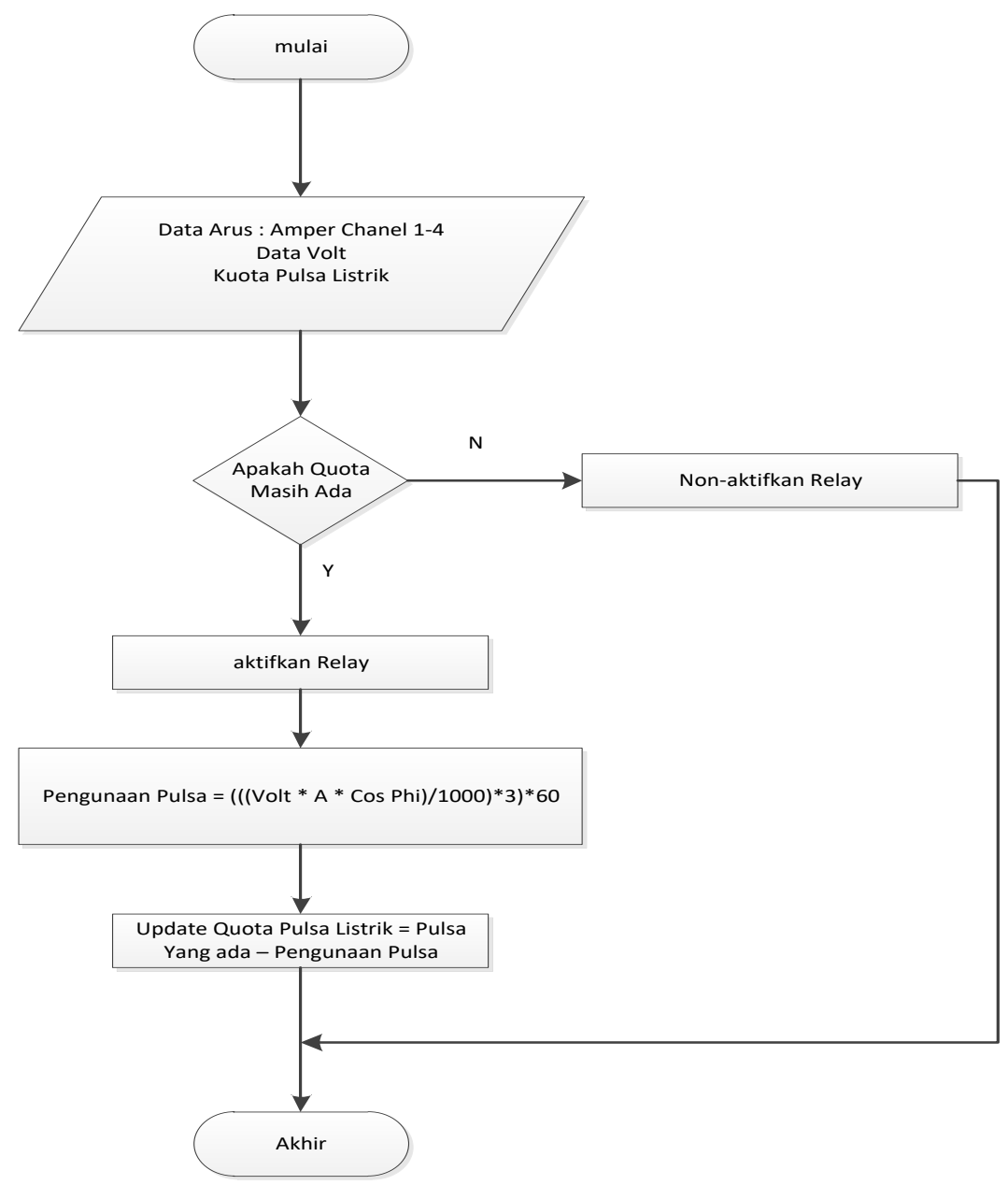

Gambar 3. Alur Program

\section{a. Perancangan Database}

Database yang digunakan dalam web service listrik prabayar pada kost mahasiswa menggunakan database MySQL. Gambar 4 terdapat dua tabel yang memiliki relasi, yaitu tabel_kwh dan tabel_user.

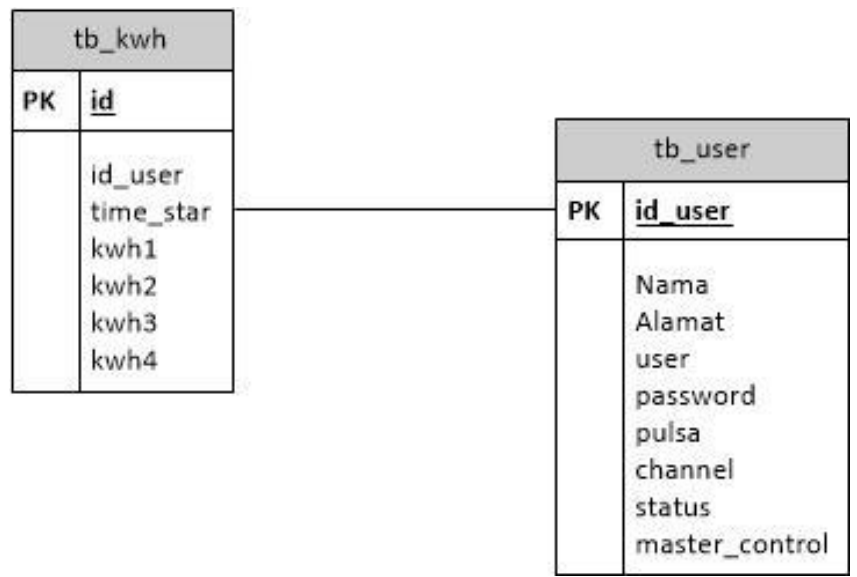

Gambar 4. Desain Database

KINETIK Vol.1, No.2, Agustus 2016, Hal. 47-54 


\section{b. Tampilan Login}

Form login pada Gambar 5 digunakan untuk membedakan pengguna antara admin dan user, serta masing-masing memiliki hak akses yang berbeda.

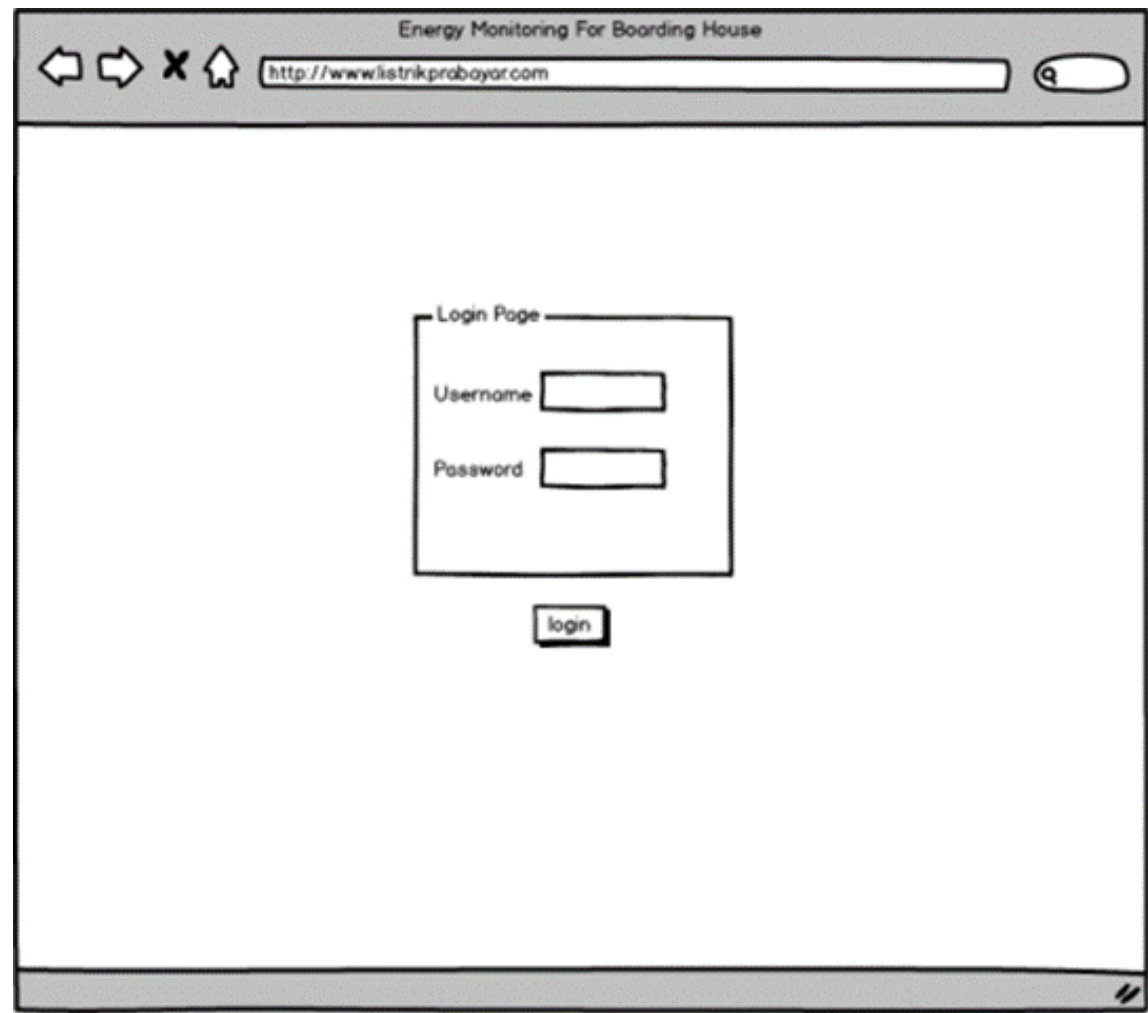

Gambar 5. Rancangan Form Login

\section{Hasil Penelitian dan Pembahasan}

Setelah tahapan pembuatan perangkat lunak selesai, maka selanjutnya akan dilakukan uji coba terhadap sistem yang dibuat. Dalam menentukan nilai uji tersebut, dilakukan pengujian sebanyak 5 kali dalam satu sesi.

Ada dua tahap pengujian sistem listrik prabayar, yakni akurasi sensor dan menguji akurasi perhitungan billing untuk jumlah benda yang diuji adalah 11 benda yang umum digunakan oleh penghuni kost. Untuk pengujian billing menggunakan 7 benda yang konstan dalam pemakaian listrik, seperti lampu, rice cooker dalam kondisi warm dan laptop. Hal ini dilakukan karena jika menggunakan beban yang tidak konstan, maka data kWh tidak akan akurat, karena lonjakan listrik berpengaruh terhadap pembacaan sensor ACS712-20A dan perhitungan billing.

Tabel 1 adalah hasil dari pengujian dari perbandingan sensor ACS712-20A dengan Multitester, beban dihubungkan dengan rangkaian secara paralel. Untuk menghitung selisih kesalahan pengukuran menggunakan Persamaan 1.

$$
\text { Selisih }=100 \%-\left(\left(\frac{x}{y} \cdot \cos p h i\right) \cdot 100 \%\right)
$$

Keterangan:

$\mathrm{x}=$ Nilai dari data sensor ACS712-20A

$y=$ Nilai dari data Multitester sebagai data acuan

cos phi $=0.8$ 
Tabel 1. Hasil Pengujian Perbandingan Sensor ACS712-20A dengan Multitester

\begin{tabular}{ccccc}
\hline No & Benda & $\begin{array}{c}\text { Data Multitester } \\
\text { (Ampere meter) }\end{array}$ & $\begin{array}{c}\text { Data sensor } \\
\text { ACS 712-02A }\end{array}$ & $\begin{array}{c}\text { Perbandingan kesalahan } \\
\text { pembacaan sensor }\end{array}$ \\
\hline 1 & Laptop & 0.10 & 0.17 & $36 \%$ \\
\hline 2 & Headter & 2.99 & 2.86 & $24 \%$ \\
\hline 3 & $\begin{array}{c}\text { Rice cooker } \\
\text { (kondisi warm) }\end{array}$ & 0.26 & 0.22 & $32 \%$ \\
\hline 4 & $\begin{array}{c}\text { Rice cooker } \\
\text { (kondisi cooking) }\end{array}$ & 1.69 & 1.51 & $29 \%$ \\
\hline 5 & Lampu & 0.10 & 0.157 & $26 \%$ \\
\hline 6 & Setrika listrik & 1.54 & 1.491 & $23 \%$ \\
\hline 7 & Bor listrik & 0.60 & 0.653 & $13 \%$ \\
\hline 8 & TV & 0.33 & 0.369 & $60 \%$ \\
\hline 9 & LCD monitor & 0.07 & 0.14 & $2 \%$ \\
\hline 10 & Solder & 0.11 & 0.14 & $31 \%$ \\
\hline 11 & Dispenser & 1.46 & 1.261 & $287 \%$ \\
\hline \multicolumn{5}{c}{} \\
\hline
\end{tabular}

Untuk mencari nilai rata-rata kesalahan pembacaan billing $\mathrm{kWh}$ menggunakan Persamaan 2.

$$
\bar{x}=\frac{x_{1}+x_{2}+\ldots+x_{n}}{n}
$$

$\bar{x}=$ rata-rata hitung

$x i=$ nilai sampel ke- $i$

$n=$ jumlah sampel

Persentase kesalahan rata-rata pengukuran sensor ACS712-20A dengan Multitester sesuai dengan Persamaan 2.

$$
\bar{x}=\frac{36 \%+24 \%+32 \%+29 \%+26 \%+23 \%+13 \%+11 \%+60 \%+2 \%+31 \%}{11}=26 \%
$$

Tabel 1 adalah hasil pengujian dengan menggunakan perhitungan Persamaan 2. Untuk melakukan pengujian akurasi billing, langkah pertama adalah mendapatkan nilai Ampere dari pengujian sebelumnya, setelah itu dari data Ampere dimasukkan ke dalam rumus kWh. Dari rumus $\mathrm{kWh}$ akan mendapatkan pemakaian listrik selama satu jam, nilai ini yang akan di masukkan ke dalam input pulsa di database, setelah itu sistem akan menghidupkan modul relay Arduino dan pada saat sensor ACS712-20A mengetahui terdapat beban sistem akan melakukan decreament pulsa. Secara bersamaan aplikasi stopwatch dihidupkan dan diamati sampai menit berapa beban akan off secara otomatis karena pulsa habis. Untuk menghitung selisih kesalahan perhitungan billing menggunakan Persamaan 3.

$$
\text { Persentase }(\%)=\left(\frac{x}{y}\right) \times 100
$$


Keterangan:

$\mathrm{x}=$ Bagian

$\mathrm{y}=$ Seluruh

Kesalahan pengukuran $\mathrm{kWh}$

$$
(\mathrm{KP})=\frac{S P H}{60} \times 100 \%
$$

Tabel 2. Hasil Pengukuran Billing Prabayar

\begin{tabular}{cccccccc}
\hline No & SB & DA & IP & SP & WKK & SPH & KP \\
\hline 1 & Lampu Phillips 23 watt & 0.14 & 0.02464 & 60 & $0: 58: 51: 58$ & $<1: 09$ Menit & $2 \%$ \\
\hline 2 & Rice cooker (kondisi warm) & 0.22 & 0.03872 & 60 & $0: 56: 38: 15$ & $<3: 02$ Menit & $5 \%$ \\
\hline 3 & Rice cooker (kondisi cooking) & 1.51 & 0.26576 & 60 & $0: 54: 00: 00$ & $<6: 00$ Menit & $10 \%$ \\
\hline 4 & Solder & 0.19 & 0.03344 & 60 & $0: 57: 16: 38$ & $<2: 44$ Menit & $4 \%$ \\
\hline 5 & LCD monitor & 0.14 & 0.02464 & 60 & $0: 59: 13: 54$ & $<0.47$ Menit & $1 \%$ \\
\hline 6 & TV & 0.37 & 0.06494 & 60 & $1: 02: 58: 00$ & $>2: 58$ Menit & $4 \%$ \\
\hline 7 & Laptop & 0.17 & 0.02992 & 60 & $0: 51: 54: 00$ & $<8: 09$ Menit & $13 \%$ \\
\hline \multicolumn{2}{c}{ Total } & & & $39 \%$ \\
\hline
\end{tabular}

Persentase kesalahan rata-rata pengukuran billing kWh sesuai dengan Persamaan 4.

$$
\text { Persentase }=\frac{2 \%+5 \%+10 \%+4 \%+1 \%+4 \%+13 \%}{7}=6 \%
$$

Keterangan:

$\begin{array}{ll}\text { SB } & : \text { Sample benda yang diuji } \\ \text { DA } & : \text { Data Ampere dari sensor ACS712-20A } \\ \text { IP } & : \text { Input Pulsa } \\ \text { SP } & : \text { Skala pengujian (Menit) } \\ \text { WKK } & : \text { Waktu kurang atau lebih } \\ \text { SPH } & : \text { Selisih perhitungan dan hasil dari alat } \\ \text { KP } & : \text { Kesalahan pengukuran kWh berdasarkan waktu }\end{array}$

Berdasarkan hasil pengujian kesalahan dalam membaca nilai Ampere adalah $26 \%$. Sedangkan billing listrik prabayar kesalahan perhitungan adalah $6 \%$, dikarenakan terjadinya fluktuasi atau tidak stabilnya pembacaan nilai Ampere.

\section{Kesimpulan}

Dari hasil pengujian maka dapat diambil kesimpulan, yaitu:

a. Error atau kesalahan pengukuran sensor ACS712-20A dengan Multitester sebesar $26 \%$ sedangkan untuk billing listrik prabayar sebesar $6 \%$.

b. Sistem listrik prabayar dapat memberikan informasi penggunaan listrik secara real-time.

c. Sistem dapat mematikan master control secara otomatis jika pada masing-masing channel mengalami kekurangan pulsa.

d. Pemilik kost dipermudah dalam melakukan manajemen pulsa listrik prabayar karena input pulsa sangat user friendly, sistem menggunakan Web Based.

e. Terdapat authentication user untuk melakukan validasi terhadap user credentials, yang ditujukan untuk menentukan apakah seorang user diperkenankan untuk mengakses layanan aplikasi.

\section{Referensi}

[1] Zipperer, Adam, et al. "Electric energy management in the smart home: Perspectives on enabling technologies and consumer behavior." Proceedings of the IEEE 101.11 (2013): 2397-2408. 
[2] Ageng Pidaksa. Wattmeter Digital AC Berbasis Mikrokontroller ATMEGA8, Yogyakarta: UNY, 2011.

[3] Budiman, Agus. "Sistem Monitoring dan Proteksi Watt Meter Multi Channel Listrik Rumah Tangga." SENTIA 2014-Politeknik Negeri Malang. 